\title{
Nas franjas da plantation: trabalho e condiçôes de vida de escravos e libertos em pequenas propriedades de Itaparica: 1840-1888*
}

\section{Wellington Castellucci Junior ${ }^{* *}$}

Este artigo procura fazer uma análise das relações de trabalho escravo e livre em pequenas propriedades rurais da Ilha de Itaparica durante as últimas décadas de escravidão no Brasil. Situada à frente da cidade do Salvador, na baía de Todos os Santos, Itaparica cumpriu, no passado, um importante papel no abastecimento de gêneros alimentícios para a capital e vilas do Recôncavo. Também é propósito deste estudo enfocar de que modo se processava o escoamento da produção dos gêneros produzidos nas roças para aqueles centros urbanos baianos.

Palavras-chave: Trabalho - Escravidão - Abastecimento

Around the fringes of plantation: the labor and life conditions of slaves and freed men in small properties of Itaparica: 1840-1888

This article is intended to present an analysis on the freed men and slaves labor relations that prevailed during Brazil's last decades of slavery, in small rural proper-

\footnotetext{
* Artigo recebido em março de 2008 e aprovado para publicação em setembro de 2008.

** Professor do Programa de Pós-Graduação, Mestrado em História Regional e Local da Universidade do Estado da Bahia. Doutor em História Social pela Universidade de São Paulo. Esta pesquisa contou com o apoio parcial da Fundação de Amparo à Pesquisa do Estado da Bahia. E-mail: wcastellucci@yahoo.com.br
} 
ties in the island of Itaparica. Located at Todos os Santos bay, right before the city of Salvador, Itaparica played in the past an important role in the supply of food to the capital city and to the villages of the "Recôncavo" area. This study also focuses how the food produced in the plantations was transported to those Bahia urban centers. Keywords: Labor - Slavery - Food Supply

Dans les franges de la plantation : le travail et les conditions de vie des esclaves et des libérés dans les petites propriétés de Itaparica : 1840-1888

Cet article cherche à élaborer une analyse sur les rapports du travail esclave et libre dans les petites propriétés agricoles de l'île d'Itaparica au cours des dernières décennies de l'esclavage au Brésil. Située en face de la ville de Salvador, dans la baie de Todos os Santos, l'île d'Itaparica a joué, dans le passé, un rôle crucial dans le ravitaillement alimentaire de la capitale et des villages de la région du Recôncavo. Le propos de cette étude est également de se pencher sur le mode d'écoulement de la production des denrées alimentaires produites dans les petites fermes vers les centres urbains.

Mots-clés: Travail - Esclavage - Approvisionnement

\section{A Fertilidade do exuberante Recôncavo}

No século XIX, a baía de Todos os Santos ainda era a principal rota de comunicação entre o vasto interior e a capital baiana. Embora os caminhos de boiadas e tropeiros trouxessem, por terra, carregamentos de algumas frutas, raízes e, sobretudo, gado bovino, procedentes do sertão ${ }^{1}$, os principais gêneros alimentícios continuavam a chegar, em grande quantidade, à praça do mercado na cidade baixa, através dos saveiros, canoas, sumacas, lanchas e outras embarcações de cabotagem, conduzidas pelos homens do mar $^{2}$. Isso era, em parte, resultado da precariedade das vias de comunicação terrestres entre a capital e o interior. Apesar de algumas iniciativas adotadas na segunda metade daquele século, no sentido de ligar as regiões mais distantes à capital,

\footnotetext{
${ }^{1}$ José Alípio Goulart, Tropas e Tropeiros na Formação do Brasil, Rio de Janeiro, Conquista, 1961.

${ }^{2}$ Kátia M. de Queiroz Mattoso, A Bahia no Século XIX. Uma Província no Império, Rio de Janeiro, Nova Fronteira, 1992, p. 63-66. Kátia M. de Queiroz Mattoso, Bahia: A cidade do Salvador e seu mercado no século XIX, São Paulo, Hucitec, 1977, p. 255.
} 
a comunicação com Salvador continuava difícil e perigosa como antes, o que, em certa medida, preocupava as autoridades provinciais da época. ${ }^{3}$

Essas dificuldades criavam obstáculos para a chegada dos gêneros de primeira necessidade bem como o consequente aumento de preços, dada a ação eficiente de atravessadores, fatos reclamados quotidianamente pela população soteropolitana. ${ }^{4}$ Em quase todo o Recôncavo, as autoridades locais enviavam correspondências queixosas contra indivíduos que se estabeleciam em lugares estratégicos dos caminhos de barro, ou nas areias da praia, a fim de comprarem produtos mais baratos e repassá-los majorados nos centros urbanos. ${ }^{5}$

Mas a falta, ou escassez desses produtos, também se justificava pela política fiscal desencadeada pelo poder público contra a navegação de cabotagem, o que, segundo alguns contemporâneos, inibia o livre trânsito das embarcações. Excesso de burocracia administrativa, tarifas elevadas, prebendas, falta de estrutura portuária para acolher barcos e descarregar imediatamente os gêneros que chegavam de diversas partes do interior, os quais muitas vezes se deterioravam antes de serem descarregados, provocavam sérios danos e prejuízos aos embarcadiços e saveiristas que ficavam muito tempo à espera do descarrego de suas mercadorias no porto. Por isso eles preferiam, muitas vezes, buscar outros meios de desembarque em alguns pontos ou enseadas do litoral para, assim, dinamizar as suas relações comerciais e driblar a vigilância, a burocracia e a tributação.

Cumprindo uma determinação por parte do poder metropolitano, quando a Bahia ainda era uma Capitania, o Conde da Ponte encomendou, em 1807, um relatório ao Senado da Câmara Municipal, o qual manifestou extrema preocupação com o abastecimento da capital ao descrever as principais causas das dificuldades do ingresso de gêneros de primeira necessidade à Bahia. Seu relator, João Rodrigues de Brito, afirmou que, dentre outras razões, enquanto navios de grande porte, procedentes inclusive de outros países, desfrutavam de grande privilégio e condescendência das autoridades portuárias:

...os Mestres porém das sumacas, e barcos dos vivandeiros ha outro direito. Começão os procedimentos pelo seqüestro do léme, e velas, ainda que o Mestre

\footnotetext{
${ }^{3}$ Mattoso, A Bahia no século XIX, op. cit., Vias de Comunicação, p. 59-66.

${ }^{4}$ Ver: Manoel Pinto de Aguiar, Abastecimento: Crises, motins e intervenção, Rio de Janeiro, Philobiblion, 1985.

${ }^{5}$ Ver a esse exemplo as correspondências enviadas pela Câmara Municipal de Jaguaripe ao Governo Provincial. APEB - Arquivo Público do Estado da Bahia, Presidência da Província, Câmara de Jaguaripe, 1861 e 1862. Maço 1.335.
} 
não seja o culpado, nem devedor, basta sua embarcação fosse transportada a farinha, ou genero qualquer, que dêo materia ao fantastico delito. E com hum tal seqüestro o priva dos meios de ganhar a vida, fazendo-lhe maior danno, do que experimentaria em pagar o que se lhe pretende extorquir, elle o exibe incontinente, sem questionar se o deve, nem pedir mais que o léme, e as velas do seu barco para fugir de hum porto, que tão benigno acolhimento presta aos que lhe vem trazer a abundancia; e se o estado de sua pequena fortuna lhe permite os meios de substituir outros instrumentos do seu officio aos aprehendidos, abandona estes, julgando-se mui feliz. ${ }^{6}$

A opressão excessiva sobre esses sujeitos, os quais viviam do transporte de mercadorias, fomentava a prática delituosa do descarrego clandestino noturno dos gêneros alimentícios, pois, "se pela escuridade da noite pode escapar ás garras dos rendeiros, e meirinhos, que elle receia mais, que os perigos do mar. Tal he a policia do nosso porto, e o favor que nelle experimenta o commercio!" As razões para tamanha fiscalização também estavam relacionadas ao fato de o comércio de alimentos estar sob o forte controle dos negros e mulatos livres desde a época colonial, o que preocupava as autoridades da época, as quais não encontravam outra solução a não ser permitirem a sua continuidade. Quando, no decorrer do século XIX, se propôs que a viagem de pessoas de cor livres, de Salvador para o Recôncavo, fosse restrita para prevenir a possibilidade de incitarem os escravos à revolta, ninguém menos que o chefe de polícia afirmou que a adoção desta medida seria não só totalmente impraticável como até ofensiva. Embora concordasse que a mesma seria boa em teoria, observou que a sua implementação resultaria na interrupção de todo o fornecimento de alimentos à cidade, porque esse comércio, na prática, era monopólio dos mulatos livres. ${ }^{8}$

Apesar de tudo, era relativamente denso o volume de embarcações que davam entrada para descarrego de mercadorias na Alfândega de Salvador e vilas portuárias, como podem atestar os registros da Alfândega de Salvador. ${ }^{9}$

${ }^{6}$ João Rodrigues de Brito, Cartas econômico-politicas sobre a agricultura e o comércio da Bahia (1821), Salvador, Arquivo Público do Estado da Bahia, 1985, p. 24. Sobre isso, ver Rafael de Bivar Marquese, Administração \& Escravidão. Idéias sobre a gestão da agricultura escravista brasileira, São Paulo, Hucitec, 1999, cap. 2.

${ }^{7}$ Idem, p. 24-25.

${ }^{8}$ A. J. R. Russell-Wood, Escravos e Libertos no Brasil Colonial, Rio de Janeiro, Civilização Brasileira, 2005, p. 99.

${ }^{9}$ APEB - Arquivo Público do Estado da Bahia. Alfândega. 020.08. Livro de pequena cabotagem, 1885-1886. Série 3/07/06; 020.03 - Entrada e saída de diversos gêneros, 1861; 020.07 - Entrada e saída de embarcações de 1831 a 1891. 
Mas eles não representavam certamente o grosso das pequenas embarcações que navegavam nas águas da baía durante o século XIX e desembarcavam gêneros na Bahia, pois era através da prática de burlar o fisco que embarcadiços, saveiristas e rendeiros subsistiam tocando seus pequenos negócios fortuitos, fugindo da tributação ostensiva. ${ }^{10}$ Enquanto uma fabulosa quantidade de navios de longo curso atracava na Alfândega de Salvador, ${ }^{11}$ aquele inveterado comércio sobreviveu durante todo o tempo, de forma paralela, longe do controle das autoridades, as quais nunca conseguiram coibir aquela atividade informal. Clandestinamente ou não, a via marítima continuava sendo, no século XIX, a opção mais viável para a chegada de mercadorias à praça do mercado de Salvador. Os embarcadiços percorriam as antigas rotas navegáveis que historicamente os conquistadores traçaram, quando adentraram rios caudalosos como o Paraguaçu, o Jaguaripe e o Jiquiriçá, além de outros que desembocam na baía e às costas da Ilha de Itaparica, para prosseguirem no processo de ocupação territorial. ${ }^{12}$

Viajantes estrangeiros que estiveram na Bahia oitocentista atestaram que essa intensa movimentação de embarcações, procedentes de diferentes localidades, entrando e saindo das imediações do porto baiano, provocava um grande rebuliço e impressionava o observador. ${ }^{13}$

Essa situação ainda perduraria no decorrer da segunda metade daquele século, pois, conforme os registros alfandegários, somente no biênio de 1885-86, uma quantidade nada desprezível de 825 embarcações de pequena cabotagem deu entrada no porto da capital. ${ }^{14}$ Curiosamente, não há registro, no livro de entrada, de nenhuma embarcação de pequeno porte procedente da Ilha de Itaparica, ${ }^{15}$ área fornecedora de "açúcar", aves e gêneros de pri-

\footnotetext{
${ }^{10}$ Ver os livros de registros de entrada e saída de mercadorias na Alfândega de Salvador. Os seguintes livros: $020.03 ; 020.05 ; 020.07 ; 020.08 ; 020.11$. Sobre protesto e descarrego de mercadorias na Alfândega de Itaparica, ver 020.57, Itaparica, 1838.

${ }^{11}$ Mattoso, A Bahia no Século XIX. Uma Província no Império, op. cit., p. 47-50.

${ }^{12}$ Mattoso, A Bahia no Século XIX. Uma Província no Império, op. cit., p. 59.

${ }^{13}$ Thomas Lindley, Narrativa de uma viagem ao Brasil, São Paulo, Cia. Editora Nacional, 1969, p. 171.

${ }^{14}$ APEB - Seção Alfândega, Doc. 020.08. Livro de Registro de Navegação de Pequena Cabotagem de Salvador, 1885-1886.

${ }^{15}$ As embarcações que apareceram no referido livro de entradas em geral são procedentes do sul da Província (Camamu, Alcobaça, Porto Seguro etc.), trazendo diversos gêneros alimentícios e outros destinados à indústria naval e mobiliária. APEB - Seção Alfândega, Doc. 020.08 .
} 
meira necessidade para a capital e vilas do Recôncavo. ${ }^{16}$ Tamanha riqueza de produtos, em termos quantitativos e qualitativos, demonstrava que, para além da grande plantation, havia um amplo leque de atividades econômicas empreendidas por escravos e forros, grandes responsáveis pelo abastecimento interno da colônia e, posteriormente, da nação em construção.

As bases para pesquisas a esse respeito já foram lançadas há algum tempo pelas historiadoras Maria Odila L. da S. Dias, ${ }^{17}$ Kátia Mattoso ${ }^{18}$ e Maria Yeda Linhares, ${ }^{19}$ além do brasilianista Stuart B. Schwartz. ${ }^{20}$ Este reclamava, em 1987, a necessidade de valorizar o papel e a importância desses sujeitos a fim de se compreender o funcionamento da economia colonial e, depois, do Império agroexportador. ${ }^{21}$ Os pequenos proprietários rurais livres, segundo esse autor, permaneciam marginais nos estudos do brasileiro, em geral sujeitos a diversas interpretações e rótulos. ${ }^{22}$

Hoje, na esteira dessa perspectiva, historiadores vêm atendendo ao apelo daquele brasilianista, empenhando-se na compreensão da escravidão brasileira. Novos olhares têm descortinado a história das populações forras e pobres livres, assim como têm buscado, através do escrutínio das fontes, compreender as relações escravistas e o trabalho livre nas pequenas propriedades rurais, a produção de alimentos, como também o envolvimento desses indivíduos no processo de abastecimento dos centros urbanos. ${ }^{23}$

${ }^{16}$ Maria Graham (1785-1842), Diário de uma viagem ao Brasil, Belo Horizonte, Itatiaia; São Paulo, Edusp, 1990, p. 177-180.

${ }^{17}$ Maria Odila L. da S. Dias, "Forros e Brancos Pobres na Sociedade Colonial do Brasil, 16751835”, in: História Geral da América Latina, UNESCO, Madri, Trota, 2001, vol. 03, cap. 14 \& "Interiorização da Metrópole (1808-1853)", in: Carlos Guilherme Mota, 1822. Dimensões, São Paulo, Perspectiva, 1986.

${ }^{18}$ Ver Mattoso, A Cidade de Salvador e Seu Mercado no século XIX, op. cit. \& Mattoso, Bahia no Século XIX, op. cit.

${ }^{19}$ Maria Yeda L. Linhares, História do Abastecimento: uma problemática em questão (1530-1918), Brasília, Binagri, 1979.

${ }^{20}$ Stuart B. Schwartz, Escravos, roceiros e rebeldes, Bauru, Edusp, 2001. Também Stuart B. Schwartz, Segredos Internos: engenhos e escravos na sociedade colonial, 1550-1835, São Paulo, Cia. das Letras, 1988.

${ }^{21}$ Essa questão também foi levantada pela historiadora Kátia M. de Q. Mattoso em seu estudo Bahia: A cidade do Salvador e seu mercado no século XIX, op. cit., parte III.

${ }^{22}$ Schwartz, Escravos, Roceiros e Rebeldes, op. cit., capítulo 3: "Roceiros e escravidão: alimentando o Brasil nos fins do período colonial”, p. 124.

${ }^{23}$ É preciso registrar a atenção pioneira dada a essa população na obra de Caio Prado Junior, in: Caio Prado Jr. História Econômica do Brasil, 32a . edição, São Paulo, Brasiliense, 1985. Formação do Brasil Contemporâneo, 13ª . edição, São Paulo, Brasiliense, 1973. Mais recentemente um importante trabalho estabelece e atualiza esta discussão. Trata-se do trabalho de 
Nesse sentido, o pressuposto de uma economia agroexportadora, baseada na grande plantation, como principal atividade a ser considerada pelos historiadores, e a convicção de que as atividades econômicas, periféricas às enormes fazendas, não mereciam atenção dos estudiosos parecem estar definitivamente esgotados. Em seu lugar, uma profusão de pesquisas tem revelado uma simbiose entre agricultura de exportação e a produção voltada para o abastecimento interno. ${ }^{24}$ A preocupação deste artigo é abordar a agricultura de gêneros alimentícios como atividade integrada aos de exportação, a qual envolvia escravos e forros. Ele discorre sobre uma região ainda muito pouco estudada, embora tão próxima da capital. Trata-se de Itaparica, o maior território insular, situado à frente da cidade do Salvador e que, no século XIX, cumpria uma importante função no abastecimento de gêneros alimentícios para a capital e vilas do interior, precisamente aquelas situadas no Recôncavo baiano. ${ }^{25}$

As reflexões feitas aqui são resultados de um intenso diálogo com um volume significativo de fontes inéditas. Inventários, Testamentos, Processos Criminais, Relatórios da Câmara Municipal de Itaparica e relatos de cronistas de época formam a base do corpus documental investigado.

\section{A vida de escravos e livres na produção das roças}

Em 1856, a Câmara Municipal de Itaparica enviou um relatório ao Presidente da Província da Bahia descrevendo aspectos da produção local cujo conteúdo dizia:

$1^{\circ}$ Produz mandioca, milho, aipim, cebola, amendoins, e mais alguns legumes, tudo em pequenas porções. Seus habitantes empregam-se

B. J. Barickman, Um Contraponto Baiano. Açúcar, fumo, mandioca e escravidão no Recôncavo, 1780-1860, Rio de Janeiro, Civilização Brasileira, 2003.

${ }^{24}$ Não são somente os estudos baianos que têm abordado as relações de trabalho e as economias periféricas à grande lavoura de exportação. Ver, por exemplo, o trabalho de João Luís Fragoso, "O Império Escravista e a República dos Plantadores. Economia Brasileira no século XIX: Mais do que uma plantation escravista-exportadora", in: Maria Yeda Linhares, História Geral do Brasil, $9^{a}$. edição, Rio de Janeiro, Campus, 2000. Ver também João Luís Fragoso, Maria Fernanda Bicalho e Maria de Fátima Gouvêa, O Antigo Regime nos Trópicos: A dinâmica Imperial Portuguesa (séculos XVI-XVIII), Rio de Janeiro, Civilização Brasileira, 2000.

${ }^{25}$ Os viajantes e cronistas de época sempre salientaram o papel que Itaparica cumpria no abastecimento de gêneros alimentícios para Salvador e vilas do Recôncavo. Ver, por exemplo, Dr. Francisco Vicente Viana, Memória Sobre o Estado da Bahia, Salvador, Tipographia do Diário da Bahia, 1893, p. 444-446. 
quase exclusivamente na pescaria, e córtes de lenha. Fabrica cal, aguardente, e pouco assucar, que nenhum augmento tem apresentado n'esses três últimos annos.

$2^{\circ}$ Exporta para a capital os mencionados gêneros e algumas frutas e verduras; quase nada importa a não ser poucos gêneros de taverna. ${ }^{26}$

Informava ainda, o Presidente da Câmara, que os produtos eram exportados através de várias embarcações, as quais saíam do seu principal porto situado na vila de Itaparica. Reclamava da falta de estradas, por onde pudessem circular pessoas e animais, em vez de tortuosos caminhos pelas praias, cujo acesso ocorria somente na vazante da maré. Mais adiante, já nos últimos parágrafos do documento, ele acrescentava mais sobre a produção de gêneros, as fábricas e os tipos de trabalho executados na Ilha:

$6^{\circ}$ Tem vinte e tantas fabricas de cal, que podem produzir mais de dês mil móis, dois pequenos engenhos de assucar, cinco alambiques de aguardentes, em tudo isso empregam-se de trezentos a trezentos e cincoenta escravos e algumas pessoas livres. Avalia-se, termo médio, em $110.000 \$ 000$ rs a importância dessas produções.

$7^{\circ}$ Nenhum melhoramento na agricultura, e na criação de gado, que custa de $40 \$$ a $50 \$ 000$ rs.

$8^{\circ}$ Augmento considerável de preço, dos gêneros alimentícios. Farinha por $1 \$ 120$ a quarta; feijão milho e arroz por preços fabulosos. Atribuise isso a falta de cultura, e ao monopólio. ${ }^{27}$

O relatório da Câmara, embora conciso, mapeava as principais atividades produtivas desenvolvidas em Itaparica, no século XIX, e os agentes responsáveis pela diversificada produção. Também enfatizava o alto custo de gêneros alimentícios por serem cultivados numa área cujo solo parecia ser pouco propício ao plantio de certos alimentos, a exemplo do arroz, do milho e do feijão. Ainda que tivesse sido o local de instalação do primeiro engenho a vapor do Brasil, ${ }^{28}$ a produção açucareira em Itaparica também não havia alcançado

${ }^{26}$ APEB - Seção Colonial/Provincial, maço 1.322. Documentos da Câmara Municipal de Itaparica, 1856.

${ }^{27} \mathrm{Idem}$

${ }^{28}$ Sobre isso, ver Ubaldo Osório, A Ilha de Itaparica: História e Tradição, Salvador, Fundação Cultural do Estado da Bahia, 1979, p. 137. Segundo esse historiador, "a máquina de moer cana” foi implantada na Fazenda Ingá-açu, de propriedade de Pedro Antonio Cardoso, situ- 
grande êxito. Muito embora o relatório fizesse referência a dois engenhos e à produção de pouco açúcar, este não assumiu importância na lista dos produtos de exportação, não ocupando grandes áreas de cultivo. ${ }^{29}$ Em vez disso, ao longo dos séculos, pequenos roceiros se firmaram em estreitas faixas de terra e desenvolveram o plantio à base do trabalho de poucos cativos e familiares, voltado para o sustento e para o abastecimento dos centros urbanos próximos. Ao seu lado, poucas fazendas de maiores dimensões mantiveram sólidas indústrias de beneficiamento de carne de baleia, engenhocas de melaço, fábricas de cal e produziam farinha em pequenas proporções. Além dessas indústrias, nas fazendas, a coleta de piaçava, do coco, do dendê, a pesca litorânea sobre canoas, usando redes de arrasto e de espera, e a coleta de crustáceos formavam um amplo mosaico de atividades produtivas sob a responsabilidade de escravos e de homens pobres livres.

O levantamento de, aproximadamente, 190 inventários, circunscritos entre 1840-1888, revelou que a maior parte das propriedades rurais de Itaparica era composta de minifúndios, com dimensões que variavam entre 10 a 800 braças de testada. A maioria distribuída pelo litoral, tendo sua frente para a baía de Todos os Santos e os fundos se perdiam pelo interior pouco ocupado. Outras estavam situadas nas proximidades da vila e dos cinco distritos. ${ }^{30}$ Mas a maior parte situava-se um pouco distante dos centros urbanos, a exemplo de locais como Barra Grande, Aroá, Barra do Gil, Conceição, Barra do Pote, Cavaco, Aratuba, Penha, locais que, ainda hoje, mantêm seus nomes da época, eram propriedades rurais, cuja nomenclatura descrita nos inventários como rocinhas, sorte de terras, sítios e chácaras, era atribuída às menores, enquanto as maiores, com maior diversidade de atividades produtivas, eram classificadas como fazendas. Em torno dessas localidades formaram-se, ao longo do tempo, povoados rarefeitos com algumas moradas de jornaleiros, poucos comerciantes portugueses e mulheres solteiras pobres que viviam de prendas domésticas ou da prestação de serviços avulsos.

ada na Freguesia de Vera Cruz, no ano de 1815.

${ }^{29}$ Além dos relatórios da Câmara Municipal, no conjunto dos Inventários não há nenhuma citação de bens ou produtos armazenados que denotasse a existência de fabricação de açúcar nas fazendas da Ilha.

${ }^{30}$ APEB - Seção dos Mapas. Mapa Estatístico da Divisão Administrativa, Judiciária e Eleitoral da Província da Bahia. Ver: Felisbelo Freire, História Territorial do Brasil: Bahia, Sergipe e Espírito Santo, v. 01, Salvador, Secretaria de Cultura e Turismo, Instituto Histórico e Geográfico da Bahia, 1998, p. 15-16. Tales de Azevedo, Povoamento da Cidade do Salvador, Col. Baiana, Ed. Itapuã, 1969. Mattoso, op. cit. Osório, op. cit. 
Provavelmente, havia, no século XIX, pouco mais de uma centena de pequenas propriedades rurais em Itaparica. Mas esse número podia variar, pois os contratos de arrendamentos e partilha de fazendas alteravam os valores anteriores. ${ }^{31} \mathrm{Na}$ maior parte delas existia uma cifra bastante reduzida de cativos, se comparados aos padrões das fazendas de grandes lavouras do continente. Somente em poucas os percentuais de cativos se destacaram das demais, chegando eventualmente à soma de trinta escravos na década de $1830 .{ }^{32}$ Mas, em 1860 e 1870, nenhuma ultrapassaria a contagem de 23 cativos. ${ }^{33}$ Ainda assim, foram pouquíssimos os inventários com tais estimativas, e o número de mulheres e crianças suplantava, em muito, o dos homens. ${ }^{34}$

Essas evidências podem sugerir que, com o fim do tráfico transatlântico, em algumas fazendas da Ilha, os escravos teriam encontrado maiores facilidades para constituírem famílias, posto ser a reprodução endógena também uma conveniência e estratégia senhorial para a reposição parcial de seus plantéis, forma pela qual se compensaria a vacância deixada pelos escravos do sexo masculino, comercializados para outras Províncias, falecidos ou alforriados. Esse foi um dos fenômenos visualizados por Cacilda Machado, Engemann e Florentino quando analisaram a situação de algumas fazendas no Sudeste escravista, as quais se encontravam distantes dos mercados de cativos. Segundo esse estudo, em algumas propriedades daquela região, conforme consta em seus respectivos inventários, os senhores puderam combinar a reposição de seus plantéis a partir da reprodução endógena com o comércio interprovincial de cativos. Fato esse constatado na proporção superior de mulheres e crianças sobre os homens, já nos primeiros anos após a proibição do tráfico de cativos procedentes da África. ${ }^{35}$

${ }^{31}$ Para uma discussão a esse respeito, ver: Francisco Carlos Teixeira da Silva, "Conflitos de Terras numa Fronteira Antiga: O sertão do São Francisco no Século XIX”, in: Revista Tempo, Departamento de História da Universidade Federal Fluminense - UFF, Rio de Janeiro, v. 4, n. 17, p. 9-28 \& Márcia Maria Menendes Motta, Nas Fronteiras do Poder. Conflito e Direito à Terra no Brasil do Século XIX, Rio de Janeiro, Vício de Leitura/Arquivo Público do Estado do Rio de Janeiro, 1998.

${ }^{32}$ APEB - Seção Judiciária, 08/3453/07. Inventário de Antonio Jose de Souza. Itaparica, 1830.

${ }^{33}$ APEB - Seção Judiciária, 05/2217/2717/20. Inventário de Maria Helena da Conceição. Itaparica, 1867.

${ }^{34}$ APEB - Seção Judiciária, 05/2067/2538/20. Inventário de Maria da Glória Dias Lima. Itaparica, 1879.

${ }^{35}$ Cacilda Machado, Carlos Engemann e Manolo Florentino, Entre o geral e o singular. Histórias de fazendas escravistas da América do Sul - séculos XVIII e XIX, in: Manolo Florentino \& Cacilda Machado (org.), Ensaios sobre a escravidão, Belo Horizonte, Editora da UFMG, 


\section{Nas franjas da plantation: trabalho e condiçôes de vida de escravos}

e libertos em pequenas propriedades de Itaparica: 1840-1888

No que tange a Itaparica, essa é uma questão que ainda carece de maiores detalhes para podermos chegar a conclusões mais consistentes. Checarmos, com maior acuidade, o perfil da escravaria das décadas anteriores a 1840 seria um dos caminhos viáveis. Porém não é fácil quantificar a população cativa que habitava Itaparica antes da execução de recenseamentos mais sistemáticos. Para a primeira metade do século XIX, os dados informados pela documentação oficial nem sempre dão pistas para se ter uma idéia aproximada da população escrava da Ilha. Uma fonte pouco confiável de 1848 acusou uma população morando em Itaparica, até aquela data, em cerca de 7.382 almas, das quais 1.595 eram considerados brancos, 4.161 pardos e 1.626 pretos. Desse total, 3.441 eram homens e 3.941 eram mulheres. O problema dessa fonte é que ela só faz referência à população livre, não constando dados acerca dos escravos. ${ }^{36}$ Somente por volta de 1872 é que os escravos ganharam visibilidade na documentação escrutinada. Conforme o censo daquela época, a população total de Itaparica girava em torno de 10.120 almas. A maior parte dela estava concentrada na vila e nos distritos. ${ }^{37}$ Estima-se que os escravos compusessem uma população de 3.292 cativos, ou seja, mais de $30 \%$ do total populacional, o que é considerado uma estimativa alta, se comparada aos percentuais do Recôncavo continental e da cidade do Salvador para a mesma época. ${ }^{38}$ Mas há controvérsia entre essa fonte e os resultados das matrículas do mesmo período que acusaram um total de 1.229 indivíduos, cerca de $10 \%$ a $12 \%$ da população, choque de dados que provocou uma discrepância absurda de $-67 \%$ dos escravos. ${ }^{39}$

2003 , p. $167-187$.

${ }^{36}$ APEB - Seção Judiciária. Quadro numérico da população livre de 14 municípios d'esta Província da Bahia. Secretaria de Polícia da Bahia, 16 de fevereiro de 1848.

${ }^{37}$ APEB. Mapa Estatístico da Divisão Administrativa, Judiciária e Eleitoral da Província da Bahia. Relação dos mapas. Ver também: APEB - Seção Histórica, Presidência da Província: Quadro da população livre e escrava da Província da Bahia. Chefatura de Polícia, 22 de abril de 1870 (documentos avulsos), in: Kátia M. de Queiroz Mattoso, Bahia: A cidade de Salvador e seu mercado no século XIX, op. cit., p. 124-125. De acordo com essa documentação, 4.630 indivíduos residiam na Vila e em suas imediações, enquanto 3.120 almas estavam no Distrito de Santo Amaro do Catu e 2.370 pessoas em toda a Vera Cruz. Os escravos somariam 910 indivíduos.

${ }^{38}$ Ver Walter Fraga Filho, "Encruzilhadas da Liberdade: Histórias e Trajetórias de Escravos e Libertos na Bahia, 1870-1910", Tese de Doutorado em História, Departamento de História da Universidade de Campinas, Campinas-SP, 2004 \&̊ João José Reis, "De Olho no Canto: Trabalho de rua na Bahia na Véspera da abolição", in: Revista Afro-Ásia, Centro de Estudos Afro-Orientais - FFCH/UFBA, Salvador, 2000, p. 199-242.

${ }^{39}$ Trata-se das matrículas dos escravos feitas entre os anos 1872-1873. Esses dados estão no levantamento feito por B. J. Barickman em seu artigo "Até a Véspera: o trabalho escravo e a produção de açúcar nos engenhos do Recôncavo baiano (1850-1881)”, in: Revista Afro-Ásia, 
As imprecisões dos dados antecedentes ao censo de 1872 e a incompatibilidade com outros registros criam certas dificuldades para se perceber a evolução da escravaria ao longo da demarcação temporal. Observando os inventários reunidos durante a pesquisa, no entanto, foi possível visualizar o seu perfil mediano, bem como sondar as mudanças nos padrões quantitativos e em termos de gênero ao longo do período, sem buscar alcançar valores absolutos de seu número. Seus resultados sugerem um rápido esvaziamento do volume de escravos, assim como o predomínio de mulheres e crianças já na década de 1850. Cruzando esses dados com outras informações, ficou evidente que muitos senhores, como já dissemos, provavelmente foram vendendo cativos do sexo masculino, para outras Paróquias e Províncias, ao passo que iam adquirindo mulheres de localidades mais próximas, além de estimularem a reprodução interna.

A vida desses escravos e de forros nas pequenas e médias propriedades rurais de Itaparica está parcialmente descrita nos processos criminais, nos inventários e testamentos de seus senhores e nas crônicas de viajantes. Suas vozes aparecem de relance; são sutilmente citados como testemunhas de conflitos e sambas envolvendo a gente humilde. Suas presenças nos lugares rurais e urbanos também são registradas por relatos afirmando suas rotinas diárias de trabalho, inclusive as noturnas, zanzando pelas ruas da vila e das povoações. Suas falas também são estridentes em inventários quando reivindicaram o compromisso de suas alforrias acordadas com o finado senhor. ${ }^{40}$

Esses registros documentais informam que os cativos nas pequenas propriedades deveriam conviver muito próximos de seus senhores; na labuta diária da roça; nos horários de almoço; descanso e dormida. Na sua quase totalidade, os inventários informam praticamente a inexistência de senzalas nas pequenas propriedades rurais. Somente em três elas apareceram como bens avaliados e discriminados. A sua não descrição ou o não arrolamento poderia evidenciar o pouco valor atribuído a elas e o desprezo dos avaliadores pelas casas de taipa, cobertas de palhas, com chão de terra batido, com porta e janela. ${ }^{41}$ Sua ausência, porém, denuncia a provável inexistência de fronteiras Centro de Estudos Afro-Orientais - FFCH/UFBA, Salvador, 1998-1999, v. 21-22, p. 177237. Ver também: Robert Slenes, "The Demography and Economic of Brazilian Slavery, 18501888", Tese de Doutoramento apresentada à Universidade de Stanford, 1976.

${ }^{40}$ APEB - Seção Judiciária, 02/874/1343/19. Inventário de Ana Rosa Oljida Marques. Itaparica, 1864.

${ }^{41}$ Semelhante situação foi verificada por Sheila de Castro Faria em sua pesquisa sobre a região de Campos de Goitacases. Segundo essa historiadora: "O que surpreende na leitura de 
simbólicas e ambientes segregados destinados à moradia dos cativos na maioria das roças. Assim, é presumível que, na maior parte das vezes, os cativos viviam debaixo do mesmo teto do seu senhor e seus familiares, acomodando-se num dos quartos ou num depósito nos fundos da casa. No máximo, eventualmente, em uma ou em outra fazenda, roça ou chácara, os avaliadores tiveram o cuidado de salientar a existência de uma senzala, um compartimento na morada do senhor ou um quarto da casa destinado à "acomodação dos pretos". ${ }^{42}$

Compartilhando os mesmos espaços de modestas ou requintadas residências na roça ou na urbe, escravos dividiram muito de suas vidas domésticas e, provavelmente, se viram sobrecarregados também pelas prendas do lar, na ausência de cativos direcionados a tais afazeres. Por outro lado, isso favorecia uma série de ganhos materiais, como as visitas noturnas à cozinha dos senhores, com ou sem a sua permissão, para furtarem alimentos e refazerem os estoques das senzalas ou dos quartos; ou ainda, agradarem um parceiro; fazerem um pirão; uma bebida para remediar enfermo; fazerem uso dos utensílios e objetos de propriedade dos senhores. Assim, às vezes, aquele compartimento era comumente utilizado pelos senhores, pelos forros e pelos escravos, mesmo quando havia uma senzala separada da moradia senhorial. Em 29 de abril de 1863, ao prestar depoimento num processo em que um escravo foi acusado de assassinar e ferir vários companheiros, numa fazenda próxima a Mar Grande, o africano cativo Bento disse, em juízo, com certa naturalidade, como se fosse uma rotina em suas vidas, que, naquela noite, "estando na cosinha de seu senhor este lhe mandara dar chá a Jacob que disse que não queria pirão, e dando-lhe o chá retirou-se elle informante para sensalla afim de deitar, e nesta ocasião ouvira seu parceiro Fauro gritar que Jacob lhe estava matando...”. ${ }^{43}$

Além de objetos pessoais e da ração fornecidos pelo senhor, à base de farinha e carne-seca, os cativos compunham sua dieta alimentar com carne de baleia moqueada e salgada, verduras, cultivadas em pequenas rocinhas que faziam nos quintais da fazenda, além das frutas que colhiam e animais

inventários do século XVIII é a ausência sistemática de senzalas, nas avaliações. Mesmo os proprietários de muitos escravos, como Salvador Esteves Lemos (Inv.177), dono de quinze escravos, em 1729, e o capitão Luiz Pinto de Queiroz (Inv.168), dono de 25 escravos, e falecido muitos anos depois (1790), não tiveram senzalas avaliadas", A Colônia em Movimento: Fortuna e Família no Cotidiano Colonial, 3ª edição, Nova Fronteira, Rio de Janeiro, 1998.

${ }^{42}$ APEB - Seção Judiciária, 02/874/1343/27. Inventário de Maria Emília Severo Navarro. Itaparica, 1864.

${ }^{43}$ APEB - Seção Judiciária, 22/778/20. Depoimento do escravo africano Bento. Processo crime contra o escravo africano Jacob. Itaparica, 1863. 
domésticos e silvestres abatidos nas matas. Complementavam sua alimentação também mariscando, apanhando ostras, caranguejos, siris, secando peixes salgados em camas de palhas, para armazená-los em sacas e irem comendo aos poucos. Alguns deles ficaram conhecidos pela habilidade na pescaria e tiveram adjetivos adicionados em seus nomes associando-os a exímios marisqueiros. Militão de Souza Anibiri declarou, no rol da escravaria de seu finado pai, um cativo angolano velho e doente, de nome "João caranguejeiro", provavelmente pelas suas habilidades em apanhar o crustáceo que grassava nos mangues de Itaparica. Isso ficou evidente porque todos os escravos, em condições de trabalho, tiveram suas profissões discriminadas no inventário. ${ }^{44}$ Ainda fazia parte da alimentação de escravos e forros, que trabalhavam nas roças, a farinha associada ao dendê cozido em tachos com água, que iam aos fornos a lenha e resultava num pirão, que eles costumavam incorporar nas refeições da manhã, antes de iniciarem a labuta, ou nos seus horários de intervalos. ${ }^{45}$

Mesmo que os escravos, além das ocupações nas roças, fossem também responsáveis por cuidarem dos víveres necessários à sua própria subsistência e à de seus familiares, havia uma forte pressão para os senhores assumirem algumas obrigações por meio das quais possibilitassem uma modesta condição de sobrevivência de sua escravaria. Além do fornecimento de moradia e parte da ração, alguns escravos também cobravam outros itens para a sua vida diária e os senhores sentiram-se compelidos a realizar essas funções, e isso não era um mero ato de espontaneidade. Dentre outras obrigações, havia o compromisso, por exemplo, do fornecimento de vestuário para os cativos, o que, em algumas ocasiões, constaram como despesas na prestação de contas nos inventários de alguns senhores. José Procópio das Mercês Pitanga, por exemplo, quando inventariou os bens de seu pai em 1868, acrescentou, no leque de despesas que teve com a moléstia e enterramento do finado, o seguinte item na época em que passou a administrar a propriedade paterna: "16\$000 Em roupa para os escravos desesseis mil reis...." ${ }^{46}$

Em certa medida, os cativos tinham muito apreço pelo que possuíam e procuravam sempre deixar um canto da senzala, ou do quarto coletivo onde

${ }^{44}$ APEB - Seção Judiciária, 08/3453/07. Inventário de Antonio José de Souza. Itaparica, 1830 .

${ }^{45}$ APEB - Seção Judiciária, 27/948/17. Processo crime contra o escravo Ismael de Tal. Itaparica, 1886.

${ }^{46}$ APEB - Seção Judiciária, 04/1399/1868/04. Inventário de José das Mercês Pitanga. Itaparica, 1868. 
moravam, para guardar suas roupas e "trastes", suas vasilhas de trabalho usadas na coleta de rochas calcárias, seus instrumentos de trabalho e musicais, potinhos de água e adornos pessoais. Eles costumavam guardar tais objetos em baús de couro velho, arcas de madeira ordinária e de pouco valor ou caixotes, dispostos próximos de suas redes, esteiras ou camas com colchões de capim onde dormiam. Numa noite tranquila de 1863, quando o escravo africano Jacob, marinheiro de lancha, assassinou e feriu vários de seus companheiros, no Mar Grande, um dos sobreviventes daquela chacina lamentou profundamente o estrago que aquele cativo havia feito nas suas coisas: "que não podendo o dito Jacob offender a elle informante metera o facão na caixa delle informante e esbandalhou a tudo...". ${ }^{77}$

Além de objetos de uso pessoal, aparecem sub-repticiamente na documentação outros itens constantes no interior das senzalas, denunciando a estrutura de moradia e os instrumentos de trabalho. Eventualmente, vemos objetos de iluminação, a exemplo dos fifós e candeeiros que alumiavam o interior da morada escrava; pequenos fogareiros de barro, onde os cativos faziam seus alimentos; instrumentos de trabalho, tais como cordas para subidas em coqueiros, selas e arreios de montaria, panacuns, balaios, facões, facas, enxadas, machados, redes de arrasto e jererés para pesca e mariscagem.

Às vezes, conflitos entre os cativos resultavam em crimes, como aquele ocorrido no Mar Grande, porque a disputa por espaço no ambiente de moradia, as divisões de ganhos nos trabalhos alternativos, a divisão ou apropriação de algum objeto de trabalho alheio poderiam resultar em atritos entre eles. Mas, para além das brigas e desavenças, havia uma espécie de reserva moral entre os cativos, na qual os mais sadios e moços costumavam amparar os mais velhos, necessitados e doentes. Alguns ex-escravos passaram a viver fluentemente na residência de seu antigo senhor, desempenhando funções de governantas, fiscais de cativos domésticos, damas de companhia de suas senhoras, domésticos simplesmente ou rendeiros. ${ }^{48}$ Mas também ficaram responsáveis por cuidar de seus antigos companheiros de cativeiro, dando-lhes de comer, sobretudo aos "inválidos", tratando dos enfermos que não mais podiam trabalhar. Em 1860, a ex-escrava Josefa Maria de Santa Anna barganhou, junto a sua patroa e

\footnotetext{
${ }^{47}$ APEB - Seção Judiciária. Depoimento do escravo Julio. Processo crime contra o escravo africano Jacob. Itaparica, 1863.

${ }^{48}$ APEB - Seção Judiciária. Processo crime contra João Theodoro Fernandes. 01/18/18. Itaparica, 1873; Processo crime contra Aristides Antonio da Cruz Meneses. Itaparica, 1875. Doc. 22/762/17.
} 
ex-senhora, um quinhão de terra depois de levar anos trabalhando na administração da casa e no trato dos cativos da fazenda, conforme atestou a senhora:

...hoje fasso separar da minha fasenda Quintas, um dos seus sítios para d'elle fazer doação a senhora Josefa Maria de Santa Anna em remuneração dos muitos serviços por ella prestados a mim, meos filhos e escravos desde que tomou conta da administração de minha casa onde tem sido empregada desde (...) ao tempo de cinco para seis annos, cujos serviços tem sido prestados com desvello e (...) e por força de minha consciencia sou obrigada a pagal-os, e por d'outra maneira não poder fasel-o, pois moeda não tenho lembro-me de cumprir tal obrigação dando-lhe o sitio da Ponta Grossa, e que fica ao lado da Ilha de fora propriedade de Antonio Gonçalves, o estimando no valor de cento e cincoenta mil reis pela pequenhez de seo terreno e mau estado de alguns coqueiros e dendezeiros existentes, mui velhos, e matos não ter, ficando demarcado o mesmo sitio pela forma seguinte (..... ${ }^{49}$

Essa liberta ainda levou consigo uma escrava africana velha avaliada em $80 \$ 000$, "doada" pela mesma senhora. Pensando na perspectiva senhorial, é provável que a senhora estivesse se livrando de um "fardo" que lhe trazia muitas "despesas". Mas é muito provável que Josefa estivesse levando consigo uma escrava, que possivelmente seria atirada na rua da amargura, passando a cuidar dela, como fizera sempre com os demais escravos da fazenda. Sua exsenhora parecia também pleitear fazer o que já havia feito com outros cativos, quando os tornou forros e, a título de concessão de um lote de terras, passou a lhes cobrar tributos pela condição de posseiros. ${ }^{50}$ Essa foi uma alternativa que vários senhores tiveram de acordar com os cativos, no curso da segunda metade do século XIX, para tentar fincar os antigos escravos em suas propriedades, evitando que eles migrassem para outras Paróquias após a liberdade. Isso trouxe mudanças na correlação de forças e maior poder de barganha por parte dos cativos, como veremos adiante.

Nas roças, diariamente, escravos e forros costumavam trabalhar na coleta de coco, na retirada de lenha para a feitura dos pacotes de madeira, enviados a Salvador e Recôncavo, além da tirada do dendê e frutas tropicais, como a fruta-pão, a banana, a manga, a laranja, além de outras. Pescavam e mariscavam para si e para seus senhores, cuidavam de alguns poucos animais e arpoavam baleias, além de fabricarem a cal. Alguns observadores contemporâneos, ao

${ }_{49}$ APEB - Seção Judiciária, 03/1024/1493/21. Inventário de Ignacia Maria de Jesus Costa. Itaparica, 1860.

${ }^{50}$ Idem. 
passarem pela Bahia e sentirem-se estimulados a conhecer a maior ilha da baía de Todos os Santos, mostraram-se demasiadamente surpresos com o modo de vida da gente daquele lugar. $\mathrm{O}$ astuto Tollenare, ao visitá-la nos primeiros anos do século, observou assim:

Conta três ou quatro engenhos, um dos quais é movido a vapor; Entretanto, possui ainda muitas matas virgens. Tem três povoações. A maior, que visitei, contém pelo menos uns 300 fogos, tem um bonito cais e é protegida por um pequeno forte. Os habitantes que não vegetam (e são em menor número) vivem da pesca da baleia; secam também peixe; há várias fábricas de azeite do lado leste e do norte. ${ }^{51}$

Além dessas atividades, havia, em algumas fazendas, uma pequena estrutura para o fabrico da farinha, provavelmente para o consumo da escravaria e abastecimento do mercado local e regional. Em geral, o lugar de fabricação era composto por uma casa, com paredes de adobe, coberta por um telheiro de pouca qualidade, com um forno, um depósito e o alguidar. ${ }^{52}$ Alguns senhores que não possuíam escravos em quantidade suficiente para a execução das tarefas sazonais, ou quando os seus poucos ficavam doentes, costumavam alugar escravos de terceiros ${ }^{53}$ ou recrutar mão-de-obra de pobres libertos, sempre disponíveis em uma região que se apresentava como uma alternativa de trabalho menos fatigante do que a labuta do eito. ${ }^{54}$ Exceto no período da Guerra do Paraguai, quando esses sujeitos estiveram dispostos a se submeter a qualquer tipo de trabalho nos canaviais para fugirem dos recrutamentos, a busca de trabalho em regiões periféricas à grande lavoura sempre foi a opção preferida dos forros. ${ }^{55}$ Essa realidade tornou-se mais flagrante na Ilha após a ${ }^{51}$ J. F. Tollenare, Notas Dominicais tomadas durante uma viagem em Portugal e no Brasil, 1816, 1817 e 1818, Salvador, Livraria Progresso, 1956, p. 218-220.

${ }^{52}$ Dentre outros Inventários, ver o de José Ramos Ferreira da Mota, datado de 1870. Nele consta a existência na propriedade de: "hum forno para queimar cal com todos os pertences, tendo um deposito avaliarão em um conto e quatro centos mil reis 1:400\$000. huma casa pequena sobre esteios, para fabrico de farinha avaliados em quarenta mil reis $40 \$ 000$ ". APEB - Seção Judiciária, 05/2060/2531/03.

${ }^{53}$ Ver: Processo crime contra Luiz Narciso. APEB - Seção Judiciária, 22/778/23. Itaparica, 1862.

${ }^{54}$ Muitos processos criminais trouxeram como depoentes libertos procedentes de outras regiões e que estavam residindo em Itaparica há pouco tempo. Às vezes esses processos arrolavam grupos de jornaleiros que provavelmente eram procedentes do mesmo lugar. Por exemplo, o Processo crime contra Germano Pacheco de Andrade arrolou vários libertos procedentes do Passé. Itaparica, 1879. APEB - Seção Judiciária, 22/762/16.

${ }^{55}$ Sobre isso, ver B. J. Barickman, "Até a Véspera", op. cit. Para efeito de estudos comparativos, ver também Peter Eisenberg, Homens esquecidos. Escravos e trabalhadores livres no 
proibição do tráfico de escravos, cujo impacto foi mais violento em regiões de pequenos proprietários e de retaguarda agrícola. Ali, os senhores não puderam concorrer com a fúria dos proprietários mais abastados do continente, que após 1850 virariam suas atenções para o mercado interno de cativos, o que se acentuou em todo o Brasil. ${ }^{56}$

\section{Relações de trabalho e a microeconomia escrava}

Por volta de 1850, os grupos de escravos de Itaparica, que anteriormente acusaram uma variante de alguns poucos sujeitos com uma tendência de maior quantidade para os homens, tenderam a declinar e apresentar uma crescente mudança em termos de proporção entre mulheres e homens, quando aquelas e as crianças foram suplantando os últimos.

Desse modo, os senhores passaram a admitir, em maior quantidade, o trabalho de jornaleiros ao lado de seus poucos cativos. Acrescente-se a essas questões o aumento no número de alforrias, flagrantemente registradas nos inventários e testamentos do período de $1850 \mathrm{em}$ diante. Mas a redução do número de cativos também se dava por conta da prática deliberada dos escravos de abandonarem as fazendas, deixando os senhores aterrorizados. Esse processo, sem dúvida, já acontecia bem antes de 1850, e alguns senhores não se esqueceram de registrar melancolicamente esse fato. Quando relacionou os bens de seu pai, morto em 1830, Militão de Souza Anibiri não se eximiu de declarar aos avaliadores que, além dos 29 escravos e escravas, africanos e crioulos, ali presentes, havia um, de nome Romão, nação Angola, que se achava fugido ${ }^{57}$. É provável que ele alimentasse a ilusão de ainda resgatá-lo, mas, a julgar pelo procedimento de outros senhores que estavam a procurar seus escravos perdidos em Comarcas distantes, sua busca foi em vão! ${ }^{58}$

Da década de 1850 em diante, a prática de recrutar serviços de trabalhadores livres estava, portanto, cada vez mais relacionada ao acentuado processo de escasseamento de escravos na região. A coexistência da escravidão com

Brasil, séculos XVIII e XIX, Campinas, Editora da Unicamp, 1989. Especialmente a primeira parte.

${ }^{56}$ Ver, sobre isso, Barickman, op.cit.

${ }^{57}$ APEB - Seção Judiciária, 08/3453/07. Inventário de Antonio José de Souza. Itaparica, 1830.

${ }^{58}$ APEB - Seção Judiciária, 63/2234/92. Pedido de captura do escravo Venâncio, fugido da Comarca de Ilhéus. Itaparica, 1884. 
o trabalho livre não era, entretanto, novidade nesse tipo de região. ${ }^{59} \mathrm{O}$ que parecia inovador era a ocupação de trabalhadores livres nos afazeres outrora destinados aos cativos, a exemplo das tiragens de cocos, coletas do dendê e outras tarefas nas roças. Muitos desses libertos eram, inclusive, ex-cativos que agora retornavam e negociavam a sua jornada de trabalho em outras bases.

Por conta dessa situação, para alguns senhores, aquela década parece ter sido fatídica. Um deles, o viúvo Pedro José de Alcântara, falecido em 1850, teve como inventariante a sua sobrinha, Ana Joaquina da Silva. Ela, que fora sua credora da quantia de trezentos mil-réis, dinheiro que pretendia destinar à compra de um escravo, foi quem assumiu o controle da fazenda e a guarda dos herdeiros menores, cuja relação com o finado não ficara explícita no testamento, sabe-se apenas que não eram seus filhos. Como administradora da fazenda, essa senhora, para se resguardar de problemas com a justiça, mostrou grande sensibilidade e preocupação em relatar toda a movimentação do trabalho escravo e livre e a produção da pequena roça de seu tio no período circunscrito entre 1850 e 1857. A ela, nós historiadores devemos a gratidão, não pelas suas atitudes escravocratas, mas por ela ter nos deixado um extraordinário registro sobre a vida daqueles sujeitos que ela e seu tio oprimiam e que, cotidianamente, trabalhavam naquela propriedade.

Esse documento, na forma de um quadro contábil e anexado ao inventário, nos fala dos dias em que um escravo trabalhou, os dias de descanso e aqueles trabalhados para o seu sustento. Essa fonte também enfatiza a participação de vários trabalhadores livres, contratados para auxiliar o escravo na execução das tarefas; o resultado da produção, além das despesas com alimentação e pagamento de salários dos jornaleiros.

Até $o$ ano de 1850 trabalhavam naquela pequena fazenda 15 cativos, dos quais sete eram mulheres crioulas e apenas uma era cabra com um filho, cinco eram homens crioulos, além de dois africanos. Diariamente, eles trabalhavam nos afazeres da casa, na coleta da piaçava, de cocos, do dendê, pescavam com redes, cuidavam de dois bois de brocha e de um cavalo lasão, cortavam a mata um pouco densa do interior da fazenda, fabricavam a cal e arpoavam baleias. Como naquela propriedade não havia armação de beneficiamento da gordura do cetáceo, ${ }^{60}$ aquele senhor costumava negociar a industrialização do óleo do ${ }^{59}$ Ver Caio Prado Jr., em seus estudos econômicos sobre o Brasil, História Econômica do Brasil, op. cit. Ver também Barickman, O Contraponto Baiano, op. cit., caps. 2, 3 e 5.

${ }^{60}$ As fábricas de desmancho e beneficiamento que transformavam o toucinho do animal em óleo combustível e comestível eram chamadas de contratos de baleia. Existiam até a década de sessenta cerca de cinco armações espalhadas pelo litoral da Ilha de Itaparica. A maior par- 
animal com algum proprietário de contrato de baleias; hábito relativamente comum na Ilha. Em seu testamento, escrito pouco antes de morrer, ele informava que:

meo sobrinho José Ant. só lhe resto quarenta mil reis, e p pagamto deste legado tenho na casa de Gonçallo José Borges, aseite de um mandrijo, q poderá ter quarenta e cinco canadas, assim como devo ao memo Gonçallo dois mil reis de resto do desmanxo, e cosinhamto do dto peixe. ${ }^{61}$

Referia-se a Gonçalo José Borges, importante fazendeiro local em cuja propriedade, situada na Barra do Gil, havia uma das armações de cozimento de baleias, ${ }^{62}$ e onde ele havia desmanchado um pequeno baleote. Esse tipo de relação envolvia, além dos pequenos proprietários destituídos de armações, os forros que, no decorrer do século XIX, também passaram a pescar e comercializar derivados de baleias em pequena escala.

Após a morte de Pedro José de Alcântara, dos 15 cativos que lhe pertenciam, sete deles foram imediatamente libertos, cumprindo a verba testamentária de sua falecida esposa e mais seis conseguiram suas alforrias, por determinação em testamento do morto, ficando somente dois africanos: $\mathrm{o}$ angola Caetano, velho e sem condições de trabalho, e o nagô Luiz, do serviço de roça, de meia idade, e ainda forte.

Não há margem para especulações acerca das razões que levaram os senhores a alforriarem a maioria da escravaria e manterem presos ao cativeiro apenas dois escravos africanos. Sabemos que um dos instrumentos, coercitivos e persuasivos, utilizados pelos senhores, no sentido de tentar controlar seus escravos, era a promessa diária de concessão da liberdade condicionada ao bom comportamento. Talvez aqueles escravos, além de serem africanos, não fizessem jus à liberdade, porque, na ótica senhorial, eles não haviam se "comportado bem", por isso excluídos do "prêmio da liberdade". Outras

te delas já se encontrava em franco processo de decadência nessa época. Sobre esse assunto, ver: Mirian Ellis, A Baleia no Brasil Colonial, São Paulo, Edusp, 1968. Mirian Ellis, "Escravos e assalariados na Antiga pesca da baleia", in: Anais do VI Simpósio Nacional dos Professores Universitários de História, vol. 1, São Paulo, 1973. Também Osório, A Ilha de Itaparica. História e Tradição, op. cit. Wellington Castellucci Jr., "Pescadores e baleeiros: a atividade da pesca da baleia nas últimas décadas dos oitocentos. Itaparica: 1860-1888", in: Revista Afro-Ásia, Centro de Estudos Afro-Orientais - FFCH/UFBA, Salvador, 2005, p. 133-168.

${ }^{61}$ APEB - Seção Judiciária, 03/990/1454/03. Inventário e Testamento de Pedro José de Alcântara. Itaparica, 1850.

${ }^{62}$ APEB - Seção Judiciária, 03/1040/1509/12. Inventário dos bens de Gonçalo José Borges. Itaparica, 1862. Ver também o Inventário de seu filho. APEB - Seção Judiciária, 05/2064/2535/23. Inventário dos bens de Lino José Borges. Itaparica, 1873. 
fontes, contudo, indicam que a "ingratidão" de muitos escravos desautorizou constantemente aquele instrumento de dominação, mostrando sua pouca eficácia, pois os senhores estavam a se queixar disso em seus testamentos. Num deles, escrito em 1885, Quitéria de Bessa, proprietária de forno de queimar cal, construído em terras no Mar Grande, afirmava, entre outras coisas, que "01 escrava de nome Amanda a qual deixo cativa pelo seu mau procedimento para comigo, que deverá o testamenteiro vende-la para com o dinheiro se pagarem as despesas". ${ }^{63}$

Fosse por essa razão ou não, os dois africanos permaneceram cativos naquela propriedade. Durante os sete anos informados pelo quadro contábil, somente o escravo Luiz continuou a trabalhar compulsoriamente na fazenda. Ele teve uma rotina anual de trabalho que variou em termos de quantidade de dias de labuta e de descanso. Por exemplo, em 1850, ele trabalhou 127 dias do total de 320 dias considerados úteis. Em 1851, trabalhou 240; em 1852, labutou 225 dias; enquanto que, em 1853, foram 233. No ano de 1854 , foram 219 dias; em 1855, trabalhou 230 e, em 1856, sua jornada foi de 248 dias anuais. Em 1857, o escravo Luiz rendeu 49 dias de trabalho, uma vez que foi o período de prestação de contas e resolução do inventário. Durante aqueles anos, Luiz trabalhou em períodos alternados e em parceria com homens livres e não mais com escravos naquilo que seria a principal fonte de renda da fazenda: a tiragem de cocos. Foram 27 tiradas que resultaram em 7.150 frutos que somaram a importância de $176 \$ 320$. Em alguns anos, as tiragens haviam sido feitas entre os meses de setembro a dezembro e, em outros, de fevereiro a junho e de setembro a dezembro. Mesmo sendo em períodos irregulares, a tiragem de cocos custeou o sustento dos menores e ainda pagou salários e alimentos dos trabalhadores livres, como informou Ana Joaquina da Silva: "Dinheiro pago aos tiradores, inclusive comedorias nas 27 tiradas de cocos com o sustento dos menores desde o dia 1 de julho de 1850, até 15 de março de 1857, q são 2:085 dias...". ${ }^{64}$

Em todo esse período, o escravo Luiz não cumpriu rigorosamente os 320 dias úteis de cada ano. Em paralelo a outras atividades na propriedade, a cada semestre ele havia reservado um tempo também para os seus afazeres pessoais. Como o trabalho compulsório na fazenda agora se restringia a ele,

${ }^{63}$ APEB - Seção Judiciária, 04/1544/2013/08. Testamento de Quitéria de Bessa. Itaparica, 1885.

${ }^{64}$ APEB - Seção Judiciária, 03/990/1454/03. Inventário e Testamento de Pedro José de Alcântara. Itaparica, 1850. 
pois aquela senhora já não podia contar com o trabalho do escravo Angola Caetano, significa que, de modo muito rápido, tinha se operado uma mudança muito expressiva nas relações de trabalho naquela fazenda. $\mathrm{O}$ desaparecimento dos escravos e a incorporação de trabalhadores livres havia se dado de forma brusca! Em suas disposições, acerca do que aqueles únicos cativos fizeram em sete anos, aquela senhora afirmava de forma lacônica que:

Do escravo Caetano nada se pode dizer em virtude de serviço algum prestar q' valha a pena ser mencionado, pelo seu mau estado; e os dias que faltão nos annos dos serviços do escravo Luiz, são os dias santos, sabbados, e domingos que tem para o seu sustento; e também os dias que tem estado doente.

Portanto, como declarou a própria administradora: nos dias santos, nos sábados e nos domingos, além dos dias em que ficara doente, o escravo Luiz guardava para si e provavelmente reservava algumas horas dos dias de trabalho também para os seus afazeres.

A descrição parcial do quotidiano de escravos e de trabalhadores livres nos afazeres da roça, inscritos nesse documento, parecem reveladores acerca de alguns detalhes das relações de trabalho no mundo rural de Itaparica. Naquela fazenda, apesar do número de escravos, anteriormente relacionados, em nenhum momento o documento fez referência às despesas com administrador ou feitor no governo dos escravos. ${ }^{65} \mathrm{Na}$ maior parte das fazendas com esse porte o absenteísmo senhorial parecia uma tônica. Os escravos, quando não estavam trabalhando ao lado de seus senhores e familiares, estavam a estipular horários e dias de trabalho para seu sustento ou afazeres que lhes rendessem algum ganho. A economia interna escrava parecia algo consolidado e inquestionável a despeito de estarem ou não sendo fiscalizados de perto. Mas as relações de dominação senhorial sobre os escravos nesse mundo rural precisam ser relativizadas, pois, nos derradeiros anos do escravismo, em algumas áreas da Ilha, houve uma pequena concentração de cativos, enquanto em outras ocorria o inverso. O número maior de escravos podia conduzir ao afastamento dos senhores de seus cativos e o aparecimento de figuras intermediárias, como feitores e administradores, entre ambos, se fizeram necessárias.

${ }^{65}$ Ver Rafael Bivar Marquese, "Paternalismo e Governo dos Escravos nas Sociedades Escravistas Oitocentistas: Brasil, Cuba, e Estados Unidos", in: Manolo Florentino e Cacilda Machado, Ensaios Sobre a Escravidão, Belo Horizonte, Editora da UFMG, 2003 \& Rafael de B. Marquese, Feitores do Corpo, Missionários da Mente, São Paulo, Cia. das Letras, 2004. 
Por volta da década de sessenta, a região de Mar Grande apresentou um pequeno surto de concentração de escravos, pois aquela área parece ter sido valorizada e alguns senhores de Salvador compraram fazendas ali e deslocaram parcelas de escravos com a finalidade de pô-los a trabalhar na fabricação da $\mathrm{cal}^{166}$. Como resultado, nas imediações de Mar Grande, foi constatada a maior concentração de escravos africanos em poucas fazendas, o que não eximiu os senhores de contratarem serviços dos libertos. Isso, em certa medida, demandou, em alguns momentos, a contratação de administradores para lidar com a escravaria em maior quantidade e porque alguns desses senhores não se faziam presentes no lugar. Porém, nas demais localidades, à medida que os senhores foram perdendo seus escravos, fosse por meio de alforrias, falecimentos, fugas ou vendas, o trabalho de jornaleiros passava a ser uma realidade cada vez mais presente no trabalho das roças, enquanto a sua escravaria minguava.

Contudo, mesmo naquelas fazendas, onde foi verificado um elevado número de escravos para os padrões do lugar, onde os senhores residiam na vila ou em Salvador e a presença do feitor fora registrada pelas fontes documentais, ela veio acompanhada do renitente registro da costumeira economia interna, do grau de autonomia conquistado e demarcado pelos escravos. ${ }^{67} \mathrm{Em}$ 1861, ao prestar depoimento acerca do crime que cometera na fazenda de seu senhor, no Mar Grande, o escravo africano João Roça, ao ser questionado por uma autoridade local, esclareceu quais eram as atividades que ocupavam ele e seus parceiros na propriedade: "Respondeo que elle interrogado hia para o arrecife tirar pedras e seo parceiro cortava capim para os cavallos e catava alguma pedra na praia". ${ }^{68}$

Apesar das ocupações com o trato dos animais e a tiragem de pedras calcárias sobre canoas nos arrecifes, situados à frente da fazenda, João Roça costumava, em horários alternados e em parceria com seu companheiro e vítima, o africano Jacob, catar pedras calcárias nas areias da praia e também irem aos arrecifes retirar pedras para a feitura da cal para eles. Ainda segundo o seu depoimento, eles costumavam comercializar o produto final e repartir

${ }^{66}$ Ver o Inventário de Ignácio Dias de Andrade. Nele consta, na prestação de contas, a venda, em 1866, de uma fazenda no Jaburu para o Sr. Ernesto José Ferreira, residente em Itapagipe. Itaparica, 1866. APEB - Seção Judiciária, 04/1544/2013/02.

${ }^{67}$ Robert W. Slenes, Na senzala uma flor. Esperanças e recordações na formação da família escrava. Brasil Sudeste, século XIX, 4ª reimpressão, Rio de Janeiro, Nova Fronteira, 1999, p. 200.

${ }^{68}$ APEB - Seção Judiciária, 27/1013/09. Processo crime do réu africano João Roça. Itaparica, 1861. 
os dividendos. Em outro momento de sua fala, ao explicar as origens da desordem, envolvendo ele e seu parceiro, Roça deixou transparecer os instrumentos usados no trabalho e como faziam para obter ganhos extras:

(...) que entre elle e seo parceiro havia uma indisposição não comentando ambos que se utilizassem de suas vasilhas e que tendo elles o costume de de noite catar pedras calcarias para fazer em seo forno cal acontece que tendo tratado com o dono da pedra ganhar cada um quatorse vinténs feito o trabalho seo parceiro Jacob recebeo a quantia toda e só lhe quis dar sete vinténs pelo que elle interrogado reclamando teve em resposta que ou recebesse o que lhe estava dando ou então que elle guardaria para si, e nisto havendo indisposições de parte a parte seus parceiros dera-lhe alguns sôcos fasendo elle interrogado vários ferimentos(?) e apartarão-se prometendo o offendido que elle interrogado lhe havia de pagar (...). ${ }^{69}$

A contenda que resultou no assassinato de Jacob teria sido em função da partilha dos lucros da comercialização da cal produzida por eles. O africano Roça parecia não estar faltando com a "verdade", considerando outras informações do processo. Conforme depoimentos de outras testemunhas, até dias antes do crime, ambos costumavam caminhar juntos para o trabalho sem atritos e "vivião em perfeita armonia", como declarou o administrador da fazenda. ${ }^{70}$ Como escravos de fazenda, eles estavam a trabalhar duramente naquelas atividades, a qual veio mais tarde a surpreender, inclusive, um pesquisador norte-americano que integrava uma comissão de estudos ictiológicos na Ilha em $1870 .^{71}$

Porém, nos horários noturnos, eles aproveitavam a folga para fazerem os seus próprios móis da cal, queimá-los em seus fornos e comercializavam, obtendo, com isso, alguns vinténs. Com o dinheiro, eles costumavam, como faziam outros escravos, ir à padaria comprar pão, cigarros nas vendas de molhados, consumir bebida espirituosa e encontrar-se comumente na povoação do Jaburu em conversas com libertos e escravos. Embora declarasse que morava na mesma fazenda, onde ocorreu o crime, desde a época em que o novo dono a comprara, o administrador nem sempre se fazia presente na mesma, pois, segundo testemunhas, havia períodos em que os escravos estavam a cuidar dos

${ }^{69}$ Idem. Depoimento do réu João Roça.

${ }^{70}$ Idem. Depoimento de Luis de Mello Brandão. Processo crime do réu africano João Roça.

${ }^{71}$ Relatório de Richard Rathbun, ajudante da Comissão Ictiológica dos Estados Unidos. Itaparica, 1870. APEB - Seção Colonial. Documento Microf. S.1, s.d. (circa 1870). 1 documento. Cópia 35 f. Inum. II - 34, 3, 2 n 2. 
afazeres sem a menor fiscalização do dito administrador. Sendo questionado, por exemplo, sobre o comportamento dos dois escravos, um negociante do Jaburu relatou, com relativa naturalidade, um pouco do quotidiano daqueles cativos:

Que conhecia o offendido, que não era turbulento que algumas veses elle offendido bebia em algumas vendas, e que o réo sempre o teve como moderado por quanto morando na fasenda não saia muitas veses no seo trabalho, mesmo na ausência do senhor (administrador - grifos meus), so na venda beber, nunca em parte alguma. ${ }^{72}$

Além das obrigações da fazenda, Jacob e João Roça também habituavam fazer o próprio translado da cal para a capital, através do saveiro do senhor, quando este não negociava com comerciantes locais, os quais compravam toda a produção e, posteriormente, a remetiam para centros comerciais maiores.

Situações semelhantes fizeram parte da rotina de escravos e forros de outras fazendas, segundo as evidências que brotam da documentação arrolada. ${ }^{73}$ Quotidianamente, na vila e nas povoações de Itaparica, havia um costume relativamente comum da presença de escravos e jornaleiros das roças caminhando pelos becos e encontrando-se nos largos, inclusive à noite, quando a penumbra recaía sobre a Ilha mal iluminada. Alguns deles mantinham o hábito de, ao se encontrarem com parceiros de trabalho, saudarem-se em língua africana, como se reportou um crioulo liberto, trabalhador de uma roça nas Amoreiras, ao ser interrogado em juízo em $1884 .^{74}$

Após a jornada de trabalho, alguns escravos, com o pouco do que ganhavam "por fora", iam, na companhia de camaradas livres, a um dos centros urbanos locais a fim de comprarem nas vendas bebidas, torresmos, fumo, cordas e facões para o trabalho de retirada de cocos, consertar instrumentos cortantes como machado, além de articularem pequenos negócios em sociedade. De resvalo, a documentação criminal, como reveladora de transgressões, aponta significativas passagens rotineiras da vida desses sujeitos. Em 1863, após um suposto incêndio criminoso de uma fábrica de cal, ocorrido, por volta das nove horas da noite, nas imediações de Mar Grande, o Subdelegado procedeu ao Inquérito Policial arrolando algumas testemunhas. Ao interrogar

${ }_{72}$ Depoimento do negociante Manoel da Silva Maxado. Processo crime do réu João Roça. ${ }^{73}$ Ver Processo crime contra João Pedro de Alcântara. APEB - Seção Judiciária, 28/979/08. Itaparica, 1888.

${ }^{74}$ APEB - Seção Judiciária, 18/615/05. Processo crime contra João Ricardo Bruno. Itaparica, 1884. 
José, escravo africano, solteiro, "tirador de pedras", suspeito de ser autor do atentado, a autoridade, depois de qualificá-lo e saber que o mesmo residia na fazenda do seu senhor na Gamboa, quis saber afinal o que ele fazia naquele lugar àquelas horas, tendo como resposta: "que estava na casa do Athanazio comprando charutos em mão do mesmo quando pelo mesmo fora dito que sabia do lugar incendiado depois retirou-se para sua casa e que não fora acudir o incêndio por não saber o lugar (...)". ${ }^{75}$

Não satisfeito com a declaração do suspeito, o Subdelegado insistiu no interrogatório perguntando: "por que razão não foi descascar os cocos com o seo companheiro como sempre fez e convidado por este negou-se?". ${ }^{76}$ Ao que o escravo José: "Respondeo que não foi por estar o ferro de discascar quebrado". 77

Após inquirir o escravo José, o Subdelegado voltou-se para interrogar o liberto Baldoino José da Rocha, morador no "Duro", Mar Grande, que se dizia pedreiro. Como este era parceiro e suposto "coiteiro" do criminoso, o Subdelegado pediu que ele narrasse o momento em que retornou para a sua casa, após o incêndio ter sido debelado, ao passo que ia fazendo algumas interpelações:

... que apenas encontrara acordado José Maria dono de huma venda junto d'sua casa, a quem comprara oitenta reis de bolaxa. Perguntado se elle respondente é o tirador de cocos de Félix de Bessa? Respondeo que sim. Perguntado como é que sendo elle respondente o tirador de cocos de Félix de Bessa como declarou não fizera esta tirada? Respondeo que não fez por lhe faltar cordas. ${ }^{78}$

Baldoino da Rocha era nativo de Itaparica, mas uma parcela expressiva de forros residentes e trabalhadores da Ilha, que apareceram envolvidos nos cerca de 65 Processos Criminais escrutinados, tinha procedência de outras Paróquias e Províncias. ${ }^{79}$ Remanescentes da escravidão, muitos deles se estabeleciam nas povoações ou na vila em busca de trabalho temporário e de reconstruírem as suas vidas após o cativeiro. Alguns viviam de fabricar cestos,

\footnotetext{
${ }_{75}$ APEB - Seção Judiciária, 29/1012/10. Inquérito policial de acusação do escravo africano José. Itaparica, 1863. Depoimento do escravo José.

${ }^{76}$ Idem.

${ }^{77}$ Idem, ibdem.

${ }^{78}$ Idem, depoimento do trabalhador Baldoino José da Rocha.

${ }^{79} \mathrm{Em}$ uma contagem feita a partir das testemunhas, vítimas e réus constantes nos processos crimes, arrolados entre os anos 1860-1888, constatei que mais de $40 \%$ deles eram procedentes de outros lugares.
} 
da pescaria, possuindo "uma canoa e rede caçoeira" ${ }^{80}$ de plantar melancias e outras frutas em terrenos baldios, conflitando com criadores de animais que deixavam o gado à solta. ${ }^{81}$ Mas também houve muitos casos em que eles foram residir nas fazendas de alguns proprietários que construíram casas para a acomodação de trabalhadores livres ao verem sua escravaria desaparecer.

As relações entre escravos e libertos nas roças, especialmente na Ilha de Itaparica, nem sempre foram harmônicas durante a vigência do escravismo. Solidariedade, amizade, relações amorosas e conflitos fizeram parte de um quotidiano permeado por disputas de espaço, demarcação de funções e diferenciação do status jurídico. Os forros, em situações bastante específicas, desejosos de se afastarem de qualquer tipo de ofício ou sinais que pudessem associá-los ao seu passado escravo, buscavam se diferenciar de seus parceiros de trabalho. Era muito difícil, às vistas grossas, fazer uma diferenciação bem categórica entre um e outro num ambiente de trabalho das roças, pois as próprias características físicas e as feições, modos de vestir e de se expressar levavam observadores a confundir escravos com forros e vice-versa. ${ }^{82}$

Por isso é que, em algumas situações, os forros se negavam a executar tarefas que eles interpretavam como "humilhantes" para a sua condição de liberto, assim como rechaçavam sarcasticamente pedidos de um cativo nos momentos de labuta ou em horários de refeição e descanso. Isso criou acirramentos entre alguns libertos e escravos, o que veio, em certas situações, a resultar em ferimentos e mortes de ambos os lados. Foi o que aconteceu na povoação de Aratuba, no dia 14 de novembro de 1886. Florinda do Amor Divino, mulher solteira, com 50 anos de idade e procedente da cidade de Nazareth das Farinhas, era moradora naquela localidade e estava servindo como diarista numa fazenda daquelas redondezas, distante cem braças do local onde ocorrera o crime. Naquela manhã, por volta das nove horas, ela escutou um tremendo estampido e, ao sair de sua casa, viu o escravo Ismael com as mãos sobre a cabeça a gritar: "Estou desgraçado, não vejo mais minha mãe, nem meo senhor". ${ }^{83}$

${ }^{80}$ APEB - Seção Judiciária, 05/2071/2542/17. Inventário dos bens de Miguel Laverroni. Itaparica, 1871.

${ }^{81}$ APEB - Seção Judiciária. Processo crime contra Conrado da Costa Lima e outro. Itaparica, 1876. Doc. 29/1013/03.

${ }^{82}$ Veja o que dizem Spix e Martius em Viagens pelo Brasil, 1817-1820, São Paulo, Edusp, p. 149.

${ }^{83}$ APEB - Seção Judiciária, 27/948/17. Processo crime contra o escravo Ismael de Tal. Itaparica, 1886. 
Naquela manhã, conforme denúncia constante no inquérito policial, o escravo Ismael havia desferido um tiro mortal de espingarda no trabalhador livre Athanazio Manoel dos Anjos, cuja morte foi imediata. No instante do crime, além de outros escravos, estava presente o parceiro de jornal da vítima, Mathias Celestino da França, que a tudo assistiu impotente. Natural de Jacuruna, parte continental do Recôncavo, trabalhava há seis meses naquela fazenda e, ao relatar o que havia ocorrido no interior de um depósito, ele deixou transparecer sintomas de rivalidades entre aquele cativo e o liberto:

Respondeu que num dia de quinta feira do mês p/passado, pelas nove horas da manhã, sahia ella testemunha de sua casa em companhia do fallecido Athanazio Manoel dos Santos, dirigião-se para a casa do capitão Leovigildo de Macedo Monteiro, onde hião trabalhar e, ao chegarem á porteira, apanharão um rolo de arame que hião levar para o trabalho de cerca, que, chegando á porta da casa do referido capitão Monteiro arriarão o rolo de arame e entrarão para apanhar o machado, onde o fallecido Athanazio dirigira-se para uma taxa que continha dendês e chegando ahi encontrára o denunciado enchendo a taxa de água; que então o denunciado pedira ao fallecido Athanazio que apanhasse um braçado de lenha, que estava na parte de fora da casa, ao que lhe respondêra pela seguinte forma: tu não te assuntas filho de beiço de caeira? Eu vou cuidar de meo trabalho, vou carregar lenha pra ti ${ }^{84}$

O que aconteceu após aquele pronunciamento foi a atitude de Ismael de pegar uma espingarda do administrador, a qual estava na sala do depósito, e descarregar sobre o abdome de Athanazio. Estava consumado um fato que trazia, em suas entrelinhas, questões relacionadas às tensões entre forros e cativos, a luta dos libertos para fugirem da condição de igual à do escravo, mas sem conseguir espaços satisfatórios de convivência no mundo socialmente excludente dos brancos. Tem razão Sheila de Castro Faria, ao afirmar que, ao libertar-se, o cativo transformava-se, aos olhos de seus companheiros, em privilegiado. No universo livre do qual, agora, fazia parte, inseria-se com emblemas nitidamente discriminatórios. ${ }^{85}$

Para além dos trabalhos de lavoura, realizados juntamente com os escravos, os forros também cumpriam uma importante função extensiva à produção dos gêneros de primeira necessidade: o transporte e o abastecimento da capital, vilas e cidades do Recôncavo. Mas essa é uma parte da História

\footnotetext{
${ }^{84}$ Depoimento de Mathias Celestino no Processo crime contra o escravo Ismael de Tal. ${ }^{85}$ Sheila de Castro Faria, A Colônia em Movimento. Fortuna e Família no quotidiano Colonial, op.cit., p. 139.
} 
que será contada em outra oportunidade. No limite desse estudo coube apenas realçar dimensões do quotidiano de escravos e forros que conviveram em pequenas propriedades rurais da Ilha de Itaparica. Da rica documentação arrolada, extraímos apenas um pouco das experiências desses sujeitos no mundo insular itaparicano. Outras dimensões de sua vida material e imaterial ainda estão por ser desentranhadas das fontes e narradas com sensibilidade e riqueza de detalhes. 